\title{
Alternative Dispute Resolution Model in the AJB Bumiputera Life Insurance Company of Purwokerto in Shari'ah Perspectives
}

\author{
Nita Triana
}

\begin{abstract}
Alternative Dispute Resolution Model in the AJB Bumiputera Life Insurance Company of Purwokerto in Shariah Perspectives. Resolution of disputes by way of litigation always takes a long time, expensive and results in a win and lose solution. Therefore resolution outside the court( non-litigation) is an alternative choice. This study analyses the resolution of insurance disputes using several methods or models outside the Court. This research is non-doctrinal legal research, with a socio-legal approach. It analyses a settlement model used by of Life Insurance AJB Bumiputera Purwokerto in the event of default of the insured/customer premium and the customer's insurance claim against the company. The settlement involves several stages, first, by means of consultation and negotiation, second by means of mediation involving OJK (Financial Services Authority) as a neutral mediator, and the last, by means of conciliation and arbitration. In the perspective of Islamic law, this solution model is similar to the concept of sulh, a type of disputes resolution in which the conflicting parties drive to settle their dispute peacefully.
\end{abstract}

Keywords: dispute resolution, sulh, AJB Bumiputera, Purwokerto

\begin{abstract}
Abstrak: Model Alternatif Penyelesaian Sengketa di Perusahaan Asuransi Jiwa AJB Bumiputera Purwokerto dalam Perspektif Syariah. Penyelesaian perselisihan dengan cara litigasi selalu membutuhkan waktu yang lama, mahal dan menghasilkan solusi menang dan kalah. Oleh karena itu resolusi di luar pengadilan (non-litigasi) adalah pilihan alternatif. Penelitian ini menganalisis penyelesaian perselisihan asuransi menggunakan beberapa metode atau model di luar Pengadilan. Penelitian ini adalah penelitian hukum non-doktrinal, dengan pendekatan hukum sosial. Studi ini menganalisis model penyelesaian yang digunakan oleh Asuransi Jiwa AJB Bumiputera Purwokerto dalam hal terjadi default dari premi tertanggung/pelanggan dan klaim asuransi pelanggan terhadap perusahaan. Penyelesaian ini melibatkan beberapa tahap, mulai dari melalui konsultasi dan negosiasi, melalui mediasi yang melibatkan OJK (Otoritas Jasa Keuangan) sebagai mediator netral, hingga melalui konsiliasi dan arbitrasi. Dalam perspektif hukum Islam, model solusi ini mirip dengan konsep sulh, sejenis resolusi perselisihan di mana pihakpihak yang bertikai berusaha menyelesaikan perselisihan mereka secara damai.
\end{abstract}

Kata Kunci: penyelesaian sengketa, sulh, AJB Bumiputera, Purwokerto

Institut Agama Islam Negeri Purwokerto

Jl. A. Yani No. 40-A Purwokerto 53126. Jawa Tengah

E-mail: triananita@iainpurwokerto.ac.id 


\section{Introduction}

Insurance in Indonesia consists of conventional insurance and sharia insurance. The development of Shariah insurance in Indonesia started by the end of 1994, namely by the inauguration of PT. Family Takaful Insurance through Minister of Finance Decree No. Kep-385/ KMK.017/1994. According to a survey from Karim Business Consulting, the market potential for sharia insurance in Indonesia can be classified, at least, into 3 potential groups: First, Those who want the insurance transaction really have a shariah orientation. This group contains a small number of individuals. Second, those who have the potential to switch from one insurance model to another. They want profit and benefits rather than their sharia values. The number of individuals in this group is large, dominant from the middle class. Third, those who have been loyal to a conventional insurance model and are difficult to move to other models because they feel comfort and trust. This group contains a relatively more individual than the first group.

Activities in the field of insurance, both conventional and sharia insurance, are inseparable from problems or disputes due to defaults such as negligence, breach of contract and not fulfilling agreement obligations. The claims submitted may be rejected by insurance companies because there are conditions that have not been met or there is a certain matter that causes claims submitted unacceptable whereas the insured feels that he has provided all the necessary information. In addition, insurance disputes may also occur due to technical errors such as the insured does not read the policy or the contents of the agreement, the officer is not assertive in explaining of the contents of the policy and clauses attached to the agreement, or there exists moral hazard (bad behavior) etc.

Courts as the first and last resort in resolving disputes are still seen by some as producing only adversarial agreements, not being able to embrace shared interests, creating new problems, taking a long time and expensive, creating antagonism among the parties to the dispute, as well as resulting ini many violations in the implementation. ${ }^{1}$ This is

${ }^{1}$ M. Natsir Asnawi, Menyoal Kompetensi Peradilan Agama dalam Menyelesaikan Perkara 
considered less profitable in the world of insurance business especially in the field of sharia insurance which requires the settlement of disputes based on sharia. On account of these situations, a new institution is needed to respond to the weaknesses of the litigation model and to provide a better solution.

In the background such conditions, there is a desire from the business community, in particular, to find alternative ways out of courtrooms to settle the disputes. The selected model is expected to provide more opportunities to get a more humane and dignified sense of justice. The idea of Alternative Dispute Resolution (ADR), a process outside litigation, is seen as generating a win-win solution, ensuring the confidentiality of the parties' disputes, avoiding delays caused by procedural and administrative matters, solving problems comprehensively through togetherness and good relationship. ${ }^{2}$

This research is non-doctrinal legal research, with a socio-legal research approach, ${ }^{3}$ that is approaching the law not only in terms of normative, but also in broader terms, including the non-doctrinal factors such as the economy, social and culture. ${ }^{4}$ The nature of this research is based on qualitative data collected through observation and interview activities. ${ }^{5}$ The researcher analyses the process of dispute resolution conducted both in Islamic and conventional insurance and the compares them to obtain a conclusion.

\section{Sharia Insurance Dispute}

Insurance is a legal instrument that ensures the representation of the obligations of an insurance company in providing protection for each

\footnotetext{
Ekonomi Syariah (Media Badilag, 2011), p. 4.

${ }^{2}$ Nita Triana, 'Reconstructing Sharia Economic Dispute Resolution Based on Indonesian Muslim Society Culture', Ijtimẩiyya: Journal of Muslim Society Research, 2.1 (2017), 107-28 <https://doi.org/10.24090/ijtimaiyya.v2i1.1099>.

${ }^{3}$ Sulistyowati Irianto, Metode Peneltian Hukum: Konstelasi dan Refleksi (Yayasan Pustaka Obor Indonesia, 2009), p. 173.

${ }^{4}$ Philippe Nonet, Philip Selznick, and Robert A. Kagan, Law and Society in Transition: Toward Responsive Law (Routledge, 2017), p. 20-110.

${ }^{5}$ Anselm Strauss and Juliet M. Corbin, Grounded Theory in Practice (Sage, 1997), p. 19.
} 
insured ${ }^{6}$ by taking the risk of loss that may be faced by the insured at some time in the future (which can not be determined when it happened), including the loss due to a death of the insured. Taking over of this risk is a consequence of fulfilling the insured's achievement, namely paying premiums on the amount and time agreed upon by the two parties.

Theoretically, the relationship of insurance law must be based on the fulfillment of 3 main principles, namely: the principle of indemnity, the principle of insurable interest, and the principle of the utmost good faith. An insured is not entitled to be compensated if he does not have an insurable interest in the object of insurance having a risk of loss, or if the insurance claim is actually greater than the actual loss. All these provisions are parts of the agreement that must be ascertained based on the utmost good faith. Not only by the insured, but also by the insurance company as the guarantor. ${ }^{7}$

Furthermore, the disputes arising from the obligation to pay premiums, allegations or alleged violations of one of the above principles often trigger disputes between the insurance company and the insured. Of course, this dispute will be very detrimental to both parties. If the dispute can not be resolved by deliberation, then it must be resolved through court or arbitration which may take considerable time, energy and costs.

${ }^{6}$ Khalid Al-Amri and Mohammad Zakir Hossain, 'A Survey of the Islamic Insurance Literature-Takaful', 2015; Mohamad Abdul Hamid and Mohd Sukki Othman, 'A Study on the Level of Knowledge and Understanding among Muslims towards the Concepts, Arabic and Shariah Terms in Islamic Insurance (Takaful)', European Journal of Social Sciences, 10, no. 3 (2009), p. 468-78. Ramin Cooper Maysami and John Joseph Williams, 'Evidence on the Relationship between Takaful Insurance and Fundamental Perception of Islamic Principles', Applied Financial Economics Letters, 2, no. 4 (2006), p. 229-32 <https://doi.org/10.1080/17446540500461778>. Maryam Dikko, 'Establishing Construct Validity and Reliability: Pilot Testing of a Qualitative Interview for Research in Takaful (Islamic Insurance)', The Qualitative Report, 21, no. 3 (2016), p. 521-28. Nico P. Swartz and Pieter Coetzer, 'Takaful: An Islamic Insurance Instrument', Journal of Development and Agricultural Economics, 2, no. 10 (2010), p. 333-39.

${ }^{7}$ Haemala Thanasegaran, 'Growth of Islamic Insurance (Takaful) in Malaysia: A Model for the Region', Singapore Journal of Legal Studies, 2008 (2008), p. 143. Sheila Nu Nu Htay and Syed Ahmed Salman, 'Viability of Islamic Insurance (Takaful) in India: SWOT Analysis Approach', Review of European Studies, 5, no. 4 (2013), p. 145. Jacky Lim, Muhammad Fahmi Idris, and Yura Carissa, 'History, Progress and Future Challenge of Islamic Insurance (Takaful) in Malaysia', in Proceedings from Oxford Business and Economics Conference Program, 2010. 
In another case, it will also be a problem when the disputed insurance claim is small. This condition makes it very difficult for the insured to resolve it through a court - let alone to use a lawyer.

\section{Breach of Contract at Life Insurance (AJB) Bumiputera}

Wirjono Prodjodikoro ${ }^{8}$ described breach of contract in insurane as follows. The first element is guaranteed party promise to pay premiums to the guarantor, all at once or gradually. The second element is the guarantor who promises to pay a certain amount of money to a guaranteed party, all at once or gradually if a third element is implemented. The third element is an event that is not yet clear but is predicted will occur.

So in an insurance agreement, the insurer promises to pay a sum of money to the insured if an uncertain event occurs, while, on the other hand, the insured promises to pay the premium as the guarantor's willingness to bear the risk. If the premium is paid the risk will switch, if the premium is not paid the risk does not switch. If the obligations are not implemented, then it is said that the parties have the breach of contract.

Article 251 KUHD explains about breach of contract in insurance by emphasizing the importance of good faith. Article 251 of the Criminal Code stipulates that all wrong or incorrect acts or concealment of circumstances known by the insured, however honest it may be on his part, in such a way that the agreement will not be held or held with the same conditions if the insurer knows the actually from the object, causing the insurance to be canceled. In insurance, there are 3 principles, namely: Principles of interest that can be insured (insurable interest) Principles of guarantee of indemnity (trustful) Principles of good faith (utmost good faith).

This principle of good faith relates to articles 1320,1321,1323,1328 and 1338 of the Civil Code and Article 251 KUHD. In Article 1338 paragraph 3 of the Civil Code, the agreement must be carried out properly and appropriately. Good faith must not only exist at the time of the

${ }^{8}$ Wirjono Prodjodikoro, Hukum Asuransi di Indonesia (Pembimbing, 1960). 
agreement but also when the agreement is made or signed. In order this principle of good faith to be fully fulfilled, the insured party should not misuse the trust given by the insurer. The insurer must also act in good faith by explaining the extent of the guarantees provided and the rights of the insured.

Article 251 of the KUHD is a special provision of articles 1321 and 1322 of the Civil Code. Its specialty is that article 251 KUHD does not consider whether the insured's actions were carried out intentionally or unintentionally. In principle, if the insurer knows the true state of the insured object, he will not hold insurance with such conditions.

The purpose of article $251 \mathrm{KUHD}$ is to protect the guarantor from the risk that is unfairly transferred to him whether the insured has good faith or not. Thus, concealment or silence of a condition about the insured object is not questioned whether it happens intentionally by the insured or because he considers the situation unimportant. ${ }^{9}$

Conversely, the breach of contract can also be made by the insurer as a guarantor. ${ }^{10}$ Suparman Sastrawidjaya, ${ }^{11}$ that the Insurer/Guarantor (the Company Insurance) has the obligation: (a). Provide compensation or give a sum of money to the Insured, if the event to be agreed to occur, except if there are things that could be a reason to release from the obligation; (b). Sign and submit the policy to the Insured; (c). Return the premium to the insured if the insurance is canceled, providing that the insured has not borne part or all of the risk.

If the Insurer does not carry out, neglects or denies the obligations as an Insurer, then the Insurer can be called to breach of contract. ${ }^{12}$ Referring to data from the Financial Services Authority, insurance is the sector that gets the most complaints from customers. This complaint is

${ }^{9}$ Abdul Manan, Hukum Ekonomi Syariah dalam Perspektif Kewenangan Peradilan Agama (Ttp.: Kencana, 2012).

${ }^{10}$ Waldi Nopriansyah, Asuransi Syariah: Berkah Terakbir Yang Tak Terduga (Yogyakarta: Penerbit Andi, 2016).

${ }^{11}$ Man Suparman Sastrawidjaja, Hukum Asuransi: Perlindungan Tertanggung, Asuransi Deposito, Usaha Perasuransian (Jakarta: Alumni, 2003).

${ }^{12}$ Robert H. II Jerry, 'Dispute Resolution, Insurance, and Points of Convergence', Journal of Dispute Resolution, (2015), p. 255. 
in the form of difficulty in paying insurance claims when the time and the event that has been agreed upon appears.

In Life Insurance AJB Bumiputera Purwokerto, the breach of contract occurs as follows: In 2017, the conventional Personal Insurance (Asper) portfolio were around 10,500 persons, and about 25\% were problematic while in the Sharia Insurance, the portfolio (in 2017) was around 2020 persons and about 15\% were problematic.

Breach of contract in the premium paid by the insured can be in the form of:

1. The insured does not pay the premium at all;

2. The insured is late paying premiums;

3. The insured has paid the premium on time but the amount of premium paid is not in accordance with the agreement.

In the Life Insurance AJB Bumiputera Purwokerto, this complaint is very rare, given that this contract is a tabarru (mutual help), so that when the insured/or policyholder delays premium payments and the next month the insured dies, the claim still be paid according to the amount of premium paid by the insured or policyholder. This is in accordance with the concept of Islamic insurance based on the Takaful concept which is a combination of a sense of responsibility and brotherhood between the parties.

Takâful comes from Arabic which is rooted in the word "kafala yakfulu" which means help to help, provide and take over someone's case. Takâful which means risking each other/mutual taking risks is the foundation of human activities as social beings. The mutual risk is carried out on the basis of mutual help by way of each person issues a benevolent fund (tabarru) which is intended to bear these risks.

But this is not the case with conventional insurance. In this type of insurance, each party holds an agreement that has been agreed by both parties. Usually, in the agreement is stated that if the insured does not pay the premium, and it turns out the next month the insured dies, the insurance claim cannot be paid. Such is in accordance with the agreement. In the Islamic view, such a contract is considered containing 
gharar because each of the two parties, the insurer and the insured at the time of the contract does not know the amount he will give and the amount he will take. All depends on whether or not the insured event occurs.

\section{Resolution of Disputes in The AJB Bumiputera Purwokerto}

When a breach of contract occurs from either the insured/policyholder or the insurer/insurance company, a conflict arises. If this conflict can not be resolved then Court becomes a choice. Resolution of insurance disputes through litigation can be done at the District Court for conventional insurance, and the Religious Court for Islamic insurance. In the Life Insurance AJB Bumiputera Purwokerto, there has never been a single case that arrived at the Court, both the District Court and the Religious Court. This phenomenon occurs because in resolving a dispute, Life Insurance AJB Bumiputera carried out various efforts outside the court, either attempted in the Life Insurance AJB Bumiputera itself or through the OJK (Financial Services Authority).

These are the stages by which the Life Insurance AJB Bumiputera resolve the disputes. The First Stage is Consultation. This method is conducted through meetings between two or more parties, aiming at discussing issues that are considered important. ${ }^{13}$ Here, consultation is used as an information and experiences exchange forum that leads to decision-making. The Consultation forum is usually carried out in one of the Life Insurance AJB Bumiputera offices. In this stage, the discussion is still around checking and rechecking data based on each version, both from the insured and the guarantor. Consultation is also used by the parties to ask or confirm data or information sources to a person or body that is considered to authority to give consideration, suggestions, or proposals. The main function of the consultation is to prevent the emergence of a dispute. ${ }^{14}$

${ }^{13}$ Margono Suyud, ADR Dan Arbitrase; Proses Pelembagaan dan Aspek Hukum (Ghalia Indonesia, Jakarta, 2000).

${ }_{14}$ Nita Triana, 'Reconstructing Sharia Economic Dispute Resolution Based on Indonesian Muslim Society Culture'. 
The second stage is the Negotiation. The basis of the negotiation is everything that is stated in the policy agreement. In most cases, the disagreement starts with the insured/the customer who is less concerned with the contents of the temporary insurance policy or from the insurer/ insurance that is less detailed in fostering the customer. Therefore, a different understanding arises. In the negotiation stage, the default problems were thoroughly discussed and the insurer pays attention to the reasons why the insured does not carry out his/her obligations. If it is proven that the insured does not carry out the obligation beyond his ability, for instance, the insured party is not charged interest.

The above-two dispute resolution may result in several solutions:

1. Selling the policy. What is meant by the policy here is a letter containing the agreement between the insured and the guarantor, the insured returns the letter with the latest premium payment receipt and receives amount of cash values for the policy.

2. Freeing premium policy. The policy goes on with the sum insured is adjusted to the amount of the free premium of the predetermined premium, while the type and period of coverage remain as before. The sum insured will be paid at the end of the insurance period or at the time of the insured's death.

3. Freeing time policy. In the event that the policy already has a value and is in arrears more than the specified period of freedom while the policyholder does not make a choice at a certain time, the policy automatically becomes a free premium policy.

The premium itself has a function as a financial return to the insured/ customer of the insurance company for risks that might occur someday. The premium must be paid monthly by the policyholder or the insured/ customer of the insurance company where the insured is registered as a user of the insurance company's insurance product service. The amount that must be paid depends on the ability of the insured and how much risk that might occur. The insurance premium component consists of basic premiums, additional premiums, reduction of company premises and tariffs. If there is a delay in premium payments, the insurance company will carry out company policies, where the policy will vary. 
In accordance with the provisions of the standard AAUI policy (Indonesian General Insurance Association), premium payments must be completed within 30 days or 1 month. If the customer does not pay the premium in accordance with the provisions within a specified time period, the policy will cancel by itself without notification of cancellation to the customer. This will certainly be very detrimental to customers because if something happens to the customer after the policy cancellation, the customer will not be able to submit a risk claim to the insurance company.

Claim failure causes the insured/customer will not be able to enjoy the facilities provided by the insurer. These conditions will also force the insured/policyholder to issue personal funds to cover all costs for the risk incurred by the insured/policyholder if in good financial condition there will probably not be a problem but if the financial condition is deteriorating then the insured/holder the policy will be in greater difficulty.

All the insured expect the claim submitted to be approved by the insurance company. However, not every risk experienced by the insured can be covered by the insurance company, all refer to the contents of the policy. Because the policy is the basis of the agreement to transfer risks from the insured to the insurer, the policy lists all the things that are guaranteed and what are excluded.

But of course, if the insurance company rejects the claim submitted by the insured, the insurance company must have the right basis for why the claim is rejected. In the case that the company has provided an explanation why the claim is rejected, but the insured feels that the claim submitted is eligible to be guaranteed as he/she has never violated all the provisions contained in the policy, then the discrepancy usually develops into a dispute.

However, the insured may find it difficult to resolve his dispute through the courtroom when the disputed insurance claim is small. Consequently, many disputes as a result of the insurance claims refusal with a small value were not resolved properly. This situation has the potential to cause 'scolding' which accumulates into 'buzzing rumors" which will be more publicly liked or disliked as uncertainty about 
protection and even neglect of the rights of insurance consumers in Indonesia.

This is one of the basic thoughts of the Indonesian insurance industry when it initiated the establishment of the Indonesian Insurance Mediation Bureau (BMAI) in 2006. BMAI presented the insurance industry as an alternative facility to settle disputes when the small-holder policyholder cannot accept the rejection of the insurance claim he submitted to the insurer.

The main objective of BMAI is to provide more space for the insured to prove whether the actions of the insurance company in rejecting the insurance claim in question are correct or not. If the adjudication examination proves that the action of rejection of claims by the insurance company is not based on law, then the company is punished to comply with the decision from BMAI. So the refusal of the insurance claim is canceled and the company cannot bring BMAI's decision to court or arbitration.

However, when the BMAI decides that the insurance company's legal refusal is justifiable, the insurance should still give freedom to the respondent to accept BMAI's decision, or to take other legal steps, by registering a lawsuit to the Court or submitting an application to Arbitration.

The BMAI is independent in handling the disputes. To ensure the justice for both parties, the BMAI examines all documents and administrative requirement, including the team handling insurance claims, before deciding to accept or reject the application. The key to maximizing the protection of insured rights is the principle of honesty and prudence.

If the steps are carried out correctly and appropriately, the number of the claims rejected by the insurance company will be minimal. Even if the insured continues to take legal action to BMAI, theoretically, there is always a tendency that insurance companies can prove the truth of their claim refusal. However, if proven otherwise, the insurance company is obliged to improve the quality of its services. At Life Insurance AJB Bumiputera such a dispute is commonly settled through a mediation model at the Financial Services Authority - OJK Purwokerto. 
The third stage is mediation. Mediation is an alternative dispute resolution applied at the Life Insurance AJB Bumiputera. The mediation occurs when the two parties still fail to agree in the negotiation method so that they need a third party as a mediator to settle the dispute. ${ }^{15}$ The mediation process can be done inside or outside the court depending on the agreement and is not binding both parties to follow or reject the suggestion. The mediation process at Life Insurance AJB Bumiputera Purwokerto was conducted at the Financial Services Authority-OJK Purwokerto with the Mediator provided by the OJK Purwokerto.

The fourth stage is Conciliation, The conciliation is a continuation of mediation on the basis of the law that regulates the problems faced by both parties. With this legal basis, the conciliator tends to pressure both parties to agree in accordance with the provisions if no further legal steps will be taken. Like in the mediation process, the conciliator at the Life Insurance AJB Bumi putera is still carried out by the Financial Services Authority - OJK.

The Fifth Stage is Arbitration. To resolve a dispute outside the court through an arbitration institution, the disputing parties should address their case in writing (arbitration clause). ${ }^{16}$ The arbitration will be conducted by an arbitration body whose decision is final and binding on the parties.

The above mentioned five ways that are carried out at Life Insurance AJB Bumiputera are supported by the Financial Services Authority (OJK) by providing LAPS (Alternative Dispute Resolution Institution) that is easily accessible, cheap, fast, and performed by experts in the financial services industry.

Based on the Financial Services Authority Regulation Number 1/ POJK.07/2014 concerning Alternative Institutions for Dispute Settlement in the Financial Services Sector, LAPS has the following principles:

${ }^{15}$ James A. Wall, John B. Stark, and Rhetta L. Standifer, 'Mediation: A Current Review and Theory Development', Journal of Conflict Resolution, 45, no. 3 (2001), p. 370-91 <https:// doi.org/10.1177/0022002701045003006>.

${ }^{16}$ Nur Khalidah Dahlan and others, 'Arbitration and Mediation Method Applied To Islamic Finance Conflicts In Malaysia', Journal of Social Science Research, 6, no. 3 (2015), p. 1151-1158. 
1. The principle of Accessibility. Dispute Resolution services are easily accessible to all consumers and cover all of Indonesia territory.

2. The principle of independence. LAPS has a supervisory organ to maintain and ensure the independence of LAPS. The institution also has adequate resources so that it does not depend on certain Financial Services Institutions.

3. Principles of justice. The mediator at LAPS acts as a facilitator in order to bring together the interests of the parties in obtaining a dispute settlement agreement, while the adjudicator and arbitrator must provide written reasons in each decision. If there is a refusal against a request of dispute settlement from consumers and Financial Services Institutions, LAPS must provide written reasons.

4. Principles of efficiency and effectiveness. LAPS charges low fees to consumers in settling disputes.

5. The principle of fast; Dispute resolution at LAPS is carried out quickly. The decision is supervised by LAPS.

There are six Alternative Dispute Settlement Institutions (LAPS) in the financial services sector which are included in the list of institutions established by the Financial Services Authority (OJK). The sixth LAPS covers the resolution of disputes in the banking, capital market and non-bank financial industry (IKNB) sectors, such as insurance, financing institutions, and pension funds.

The existence of LAPS is emphasized as the choice of dispute resolution forum in the financial industry. As Article 45 paragraph (2) of the Consumer Protection Law states, the settlement of consumer disputes can be taken either through the court or outside the court based on the voluntary choice of the parties to the dispute. To support the existence of LAPS as a mandatory path when financial disputes arise, there is a policy for the inclusion of dispute resolution clauses through LAPS in each agreement or contract between consumers and PUJK. OJK claims that the 'standard clause' is permissible as long as it does not conflict with the freedom of contract, the legal terms of the agreement, an equal position and no misuse of circumstances. 
Alternative dispute resolution between the insurance company and the insured through the LAPS-BMAI set by the OJK, is an agreement that does not conflict with the principles of fairness and propriety as the settlement step through the mediation or adjudication stage basically bind only the insurer, not the insured.

In addition, in the mediation and adjudication process, the party submitting the case is the Insured. Therefore, even though the dispute resolution agreement through the LAPS has attained a solution, the implementation of these provisions constitutes the exclusive rights of the insured. In other words, the insured has full authority to use it or not, and also has full authority to comply or not. This is different from arbitration which cannot be separated from the provisions of Law No. 30 of 1999 concerning Arbitration and Alternative Dispute Resolution. ${ }^{17}$ The choice of dispute settlement through Arbitration is a provision that must be explicitly chosen by both the insurer and the insured.

\section{Sulh an Islamic Alternative Dispute Resolution}

According to legal sociology, ${ }^{18}$ that is more concerned with the function of the institution, the factor of the institution that carries out the function of adjudicating is unimportant. ${ }^{19}$ Decisions about justice can be done anywhere in the community, not necessarily in the courtroom. Therefore, enforcing and finding justice must not only be done through the formal structure of the court institution. The trial function can be done and takes place in many locations, which Marc Galanter Marck Galanter, ${ }^{20}$ expressed as "justice in many rooms."

Likewise, the methods or models that can be used to resolve disputes do not necessarily depend on very formal methods like in the

${ }^{17}$ Said Agil Husein al-Munawwar, 'Pelaksanaan Arbitrase di Dunia Islam, dalam Arbitrase Islam Indonesia', Jakarta: BAMUI \& BMI, 1994.

${ }^{18}$ Satjipto Rahardjo, 'Hukum Progresif: Hukum Yang Membebaskan', Jurnal Hukum Progresif, 1, no .1 (2011), p. 1-24.

${ }^{19}$ Boaventura de Sousa Santos, Toward a New Common Sense Law, Science and Politics in the Paradigmatic Transition, 1995.

${ }^{20}$ Galanter Marck, 'Justice in Many Rooms: Court, Privat Ordering and Indigenous Law', The Journal of Legal Pluralism. no. 19, (1981). 
Court. Alternative Dispute Resolution, such as consultation, negotiation, mediation, conciliation, and arbitration can be carried out as long as it is approved by the parties. On the basis of this, choosing an arbitration forum or mediation to resolve business disputes is a tendency to shift the interest of justice seekers from using litigation in the courts to other channels which format is more formally unstructured. This method is more able to realize justice and still be able to maintain peace between the parties.

One way to resolve the dispute in a peaceful manner in Islam known as sulh. Sulh is a highly recommended method of resolving conflicts. ${ }^{21}$ Sulh can be interpreted as a settlement of disputes in a peaceful manner that includes various ways of settlement such as negotiation, mediation/ conciliation, and compromise of actions (negotiation, mediation/ conciliation and compromise of action $)^{22}$ The word sulh comes from Arabic which means to reconcile or to make peace with an opponent. Sulh comes from the verb saluha or salaha which practically means 'to be good, right' and "to express the idea of peace and reconciliation".

The concept of sulh (peace), as mentioned in various figh books, is a major doctrine of Islamic law in the field of muamalah to resolve

${ }^{21}$ George E. Irani and Nathan C. Funk, 'Rituals of Reconciliation: Arab-Islamic Perspectives', Arab Studies Quarterly, 20, no. 4 (1998), p. 53-73. George E. Irani and Jordan Lebanon, 'Islamic Mediation Techniques for Middle East Conflicts', Middle East, 3, no. 2 (1999), p. 2. Işık Tamdoğan, 'Sulh and the 18 Th Century Ottoman Courts of Üsküdar and Adana', Islamic Law and Society, 15, no. 1 (2008), p. 55-83. Kamal Halili Hassan, 'Employment Dispute Resolution Mechanism from the Islamic Perspective', Arab Law Quarterly, 20, no. 2 (2006), p. 181-207. Md Zahidul Islam, 'Provision of Alternative Dispute Resolution Process in Islam', Journal of Business and Management, 6, no. 3 (2012). Ramizah Wan Muhammad, 'The Theory and Practice of Sulh (Mediation) In The Malaysian Shariah Courts', IIUM Law Journal, 16, no. 1 (2008) <https:// doi.org/10.31436/iiumlj.v16i1.42>. Abu Bakar and Zainul Rijal, 'Sulh in the Malaysian Shariah Courts', Rediscovering Mediation in the 21st Century. Kuala Lumpur: Asia Mediation Association; Malaysia's Leading Law Publisher, 2011. Nora Abdul Hak and Hanna Ambaras Khan, 'The Application of Sulh in Resolving Community Disputes', In World Congress on Integration and Islamicisation of Human Knowledge, Kular Lumpur. 2013. Raini Hassan, Hanna Ambaras Khan, Imad Fakhri Al-Shaikhli, and Nora Abdul Hak. "Setting-up a Sulh-Based, Community MediationType of Online Dispute Resolution (ODR) in Malaysia." In Information and Communication Technology for the Muslim World (ICT4M), 2013 5th International Conference on, IEEE, 2013, p. 1-6. Sa'odah Ahmad, and Nora Abdul Hak. "Family Mediation and Sulh: An Alternative Dispute Resolution in Malaysia." International Journal of Social Policy and Society 7 (2010): p. 66-79.

${ }^{22}$ Syed Khalid Rashid, 'Alternative Dispute Resolution in the Context of Islamic Law', The Vindobona Journal of International Commercial Law and Arbitration, 8, no. 1 (2004), p. 95-118. 
a dispute. It is already a condition of sine qua non in the life of any society because in essence peace is not merely a positive institution, but more in the form of nature of humans. ${ }^{23}$ All human beings dream of all aspects of their lives to be comfortable, harmonious, peaceful.

Sulh literally also means "ending a dispute (to end a dispute) or" cutting off a dispute "(to cut off a dispute), either directly or with a neutral third party (a third neutral party). According to Ibn Qudamah, sulh is a negotiation between two disputing parties leading to peace. According to, al-Ahkam al-Adliyyah Article 1531, Sulh is a contract which removes disputes with an agreement and it becomes a contract agreed upon with the offer (acceptance) and acceptance. ${ }^{24}$

The above definition indicates that the purpose of sulh is to end the conflict and hostility between the parties peacefully so that they can continue to establish relations. Sulh is a resolution based on the conciliation negotiated by the parties to the dispute, either alone or with the help of a third party based on the agreement of the parties. Contracts that have been mutually agreed upon by the parties, become morally binding, of course, To bind the peace legally it can be made in writing.

The use of sulh in resolving disputes is highly recommended in Islam. There are several verses of the Qur'an and the hadith of the Prophet Muhammad that explain the important functions of sulh as follows:

"And if a woman is worried about nusyuz or an indifferent attitude from her husband, then there is no reason for both of them to hold true peace, and peace is better (for them) even though human beings are stingy according to their nature, and if you associate with your wife good and take care of yourself (from nusyuz and indifference), then verily Allah is the Knower of what you do." (Q.s. al-Nisa' [4]: 128)

"Peace is a good deed." (Q.s. al-Nisa' [4]: 126)

${ }^{23}$ Aseel al-Ramahi, 'Sulh: A Crucial Part of Islamic Arbitration. LSE Law', Society and Economy Working Papers, 12 (2008).

${ }^{24}$ Abdul Rasyid, 'Relevance of Islamic Dispute Resolution Processes in Islamic Banking and Finance', Arab Law Quarterly, 27, no. 4 (2013), p. 343-69 <https://doi.org/10.1163/15730255$12341267>$. 
"And if there are two groups of young people fighting then reconcile between the two ..." (Q.s. al-Hujurat [49]: 9)

The paragraph above clearly encourages the disputing parties to resolve their dispute in a peaceful manner (amicable means).

The Prophet Muhammad also recommended a peaceful resolution of disputes as he said" ${ }^{25}$ : "Conciliation between Muslims is permitted, except conciliation which makes everything that is harâm (unlawful) becomes halâl (lawful) and halâl (lawful) becomes harâm (unlawful)". In line with the hadith, there is also a famous treatise written by Umar bin Khattab, the second Islamic Caliph, to Abu Musa Al-Ash'ari, when the later was appointed as a judge (qâdi). The letter contains various orders relating to the administration of justice. One is related to sulh which reads: "All kinds of compromises and conciliations among Muslims are permitted, except forbidding everything that is lawful and lawful to be forbidden." Likewise in terms of jurisprudence, there is a rule which states that sulh is the main instrument of legal settlement (al-Sulh Sayyid al-Ahkâm). Based on the Prophet's hadith and the letter of Umar mentioned above, it is important to note that the use of conciliation and compromise to resolve disputes is highly recommended.

In Islamic law, mediation, conciliation, and negotiation are carried out informally and are not regulated by formal regulations, just as current mediation institutions tended to be institutionalized by various formal rules and mechanisms. If there is no solution attained, then the two parties may appoint a third party (mediator, muhakkim/arbiteir) to help resolve the dispute. There are several types of solutions involving third parties as mediators in Islam such as Tahkim, Al hisbah and various ways based on sulh (peace). ${ }^{26}$

${ }^{25}$ HANES Wahed, 'Sulh: Its Application in Malaysia', IOSR Journal of Humanities and Social Sciences, 20, no. 6 (2015), p. 71-79.

${ }^{26}$ Wahbah al-Zuhaili, 'Figh Islam Wa Adillatuhu, Jilid 10', (Jakarta: Gema Insani, 2011). 


\section{Conclusion}

In the Life Insurance AJB Bumiputera Purwokerto, either sharia insurance or conventional insurance, no case has ever entered to Judicial body either Religious Court or District Court. All of the disputes relating to the breach of contract were settled by a non-litigation solution. This may be done, at an initial stage, through consultation and negotiation, where the insured and the insurer meet to convey data according to their perceptions, then bargain for the amount of premium or changes the status of the policy for the benefits of the parties. If these methods fail to achieve a solution, then the two parties may come to OJK (Financial Services Authority) as a neutral mediator to help the parties find a way out. If this method also fails to achieve a solution, then the disputing parties may resolve it through a line of conciliation and arbitration by presenting a third party as the referee who can decide the resolution of the dispute on the basis of evidence and witnesses.

The places where the two parties seek justice outside the Court, which Marck Galanter calls Justice in Many Rooms, is not a state court building, but a place/space where the parties seek justice, such as in the Life Insurance AJB Bumiputera Purwokerto office or in the OJK (Financial Services Authority) or anywhere according to the agreement of the parties. In the perspective of Islamic law, the model of seeking justice in various ways and spaces (justice in many rooms) carried out by the Life Insurance AJB Bumiputera Purwokerto is similar to the concept of sulh, a type of contract or agreement to end disputes/quarrels peacefully. In the sulh, dispute resolution can be done directly by means of consultation and negotiation, or by appointing third parties (muhakkim/arbiteir) to help resolve the disputes, such as the Tahkim, Mediation, and al-Hisbah models. Resolving a dispute based on peace is highly recommended by Allah Swt as stated in the Surah al-Nisa ' [4] verse 126 stating: "peace is a good deed."

\section{Bibliography}

Abdul Hak, Nora, and Hanna Ambaras Khan, 'The Application of Sulh in Resolving Community Disputes', 2013. 
Ahmad, Sa'odah, and Nora Abdul Hak. "Family Mediation and Sulh: An Alternative Dispute Resolution in Malaysia." International Journal of Social Policy and Society 7, (2010): 66-79.

Amri, Khalid al-, and Mohammad Zakir Hossain. 'A Survey of the Islamic Insurance Literature-Takaful', 2015.

Munawwar, Said Agil Husein al-. 'Pelaksanaan Arbitrase Di Dunia Islam, Dalam Arbitrase Islam Indonesia’. Jakarta: BAMUI \& BMI, 1994. Ramahi, Aseel al-. 'Sulh: A Crucial Part of Islamic Arbitration. LSE Law', Society and Economy Working Papers, 12 (2008), 2008.

Asnawi, M. Natsir, Menyoal Kompetensi Peradilan Agama Dalam Menyelesaikan Perkara Ekonomi Syariah (Media Badilag, 2011).

Zuhaili, Wahbah al-. 'Fiqh Islam Wa Adillatuhu, Jilid 10', Jakarta: Gema Insani, 2011.

Bakar, Abu, and Zainul Rijal, 'Sulh in the Malaysian Shariah Courts', Rediscovering Mediation in the 21st Century. Kuala Lumpur: Asia Mediation Association; Malaysia's Leading Law Publisher, 2011

Dahlan, Nur Khalidah, Mohd Rizal Palil, Noor Inayah Yaaâ, and Mohamad Abdul Hamid. 'Arbitration and Mediation Method Applied To Islamic Finance Conflicts In Malaysia', Journal of Social Science Research, 6 (2015), 1151-1158.

Dikko, Maryam. 'Establishing Construct Validity and Reliability: Pilot Testing of a Qualitative Interview for Research in Takaful (Islamic Insurance)', The Qualitative Report, 21 (2016), 521-28.

Hamid, Mohamad Abdul, and Mohd Sukki Othman. 'A Study on the Level of Knowledge and Understanding among Muslims towards the Concepts, Arabic and Shariah Terms in Islamic Insurance (Takaful)', European Journal of Social Sciences, 10 (2009), 468-78.

Hassan, Kamal Halili. 'Employment Dispute Resolution Mechanism from the Islamic Perspective', Arab Law Quarterly, 20 (2006), 181-207.

Hassan, Raini, Hanna Ambaras Khan, Imad Fakhri Al-Shaikhli, and Nora Abdul Hak. "Setting-up a Sulh-Based, Community Mediation-Type of Online Dispute Resolution (ODR) in Malaysia." In Information 
and Communication Technology for the Muslim World (ICT4M), 2013 5th International Conference on, IEEE, 2013.

Htay, Sheila $\mathrm{Nu} \mathrm{Nu}$, and Syed Ahmed Salman. 'Viability of Islamic Insurance (Takaful) in India: SWOT Analysis Approach', Review of European Studies, 5 (2013), 145.

Irani, George E., and Nathan C. Funk. 'Rituals of Reconciliation: Arab-Islamic Perspectives', Arab Studies Quarterly, 20 (1998), 53-73.

Irani, George E., and Jordan Lebanon. 'Islamic Mediation Techniques for Middle East Conflicts', Middle East, 3 (1999), 2.

Irianto, Sulistyowati. Metode Peneltian Hukum: Konstelasi dan Refleksi. Yayasan Pustaka Obor Indonesia, 2009.

Islam, Md Zahidul. 'Provision of Alternative Dispute Resolution Process in Islam', Journal of Business and Management, 6 (2012).

Jerry, Robert H. II. 'Dispute Resolution, Insurance, and Points of Convergence', Journal of Dispute Resolution, 2015 (2015), 255.

Lim, Jacky, Muhammad Fahmi Idris, and Yura Carissa. 'History, Progress and Future Challenge of Islamic Insurance (Takaful) in Malaysia', in Proceedings from Oxford Business and Economics Conference Program, 2010.

Manan, Abdul. Hukum Ekonomi Syariah dalam Perspektif Kewenangan Peradilan Agama. Ttp.: Kencana, 2012.

Marck, Galanter. 'Justice in Many Rooms: Court, Privat Ordering and Indigenous Law', The Journal of Legal Pluralism. no. 19, (1981).

Maysami, Ramin Cooper, and John Joseph Williams. 'Evidence on the Relationship between Takaful Insurance and Fundamental Perception of Islamic Principles', Applied Financial Economics Letters, 2 (2006), 229-32 <https://doi.org/10.1080/17446540500461778>.

Muhammad, Ramizah Wan. 'The Theory and Practice of Sulh (Mediation) In The Malaysian Shariah Courts', IIUM Law Journal, 16 (2008) <https://doi.org/10.31436/iiumlj.v16i1.42>.

Nonet, Philippe, Philip Selznick, and Robert A. Kagan. Law and Society in Transition: Toward Responsive Law. Routledge, 2017. 
Nopriansyah, Waldi. Asuransi Syariah: Berkah Terakhir Yang Tak Terduga. Yogyakarta: Penerbit Andi, 2016.

Prodjodikoro, Wirjono. Hukum Asuransi di Indonesia. Pembimbing, 1960.

Rahardjo, Satjipto. 'Hukum Progresif: Hukum Yang Membebaskan', Jurnal Hukum Progresif, 1 (2011), 1-24.

Rashid, Syed Khalid. 'Alternative Dispute Resolution in the Context of Islamic Law', The Vindobona Journal of International Commercial Law and Arbitration, 8 (2004), 95-118.

Rasyid, Abdul. 'Relevance of Islamic Dispute Resolution Processes in Islamic Banking and Finance', Arab Law Quarterly, 27 (2013), 343-69 <https://doi.org/10.1163/15730255-12341267>.

Santos, Boaventura de Sousa. Toward a New Common Sense Law, Science and Politics in the Paradigmatic Transition, 1995.

Sastrawidjaja, Man Suparman. Hukum Asuransi: Perlindungan Tertanggung, Asuransi Deposito, Usaha Perasuransian. Jakarta: Alumni, 2003.

Strauss, Anselm, and Juliet M. Corbin. Grounded Theory in Practice. Sage, 1997.

Suyud, Margono. ADR dan Arbitrase: Proses Pelembagaan dan Aspek Hukum. Jakarta: Ghalia Indonesia, 2000.

Swartz, Nico P., and Pieter Coetzer. 'Takaful: An Islamic Insurance Instrument', Journal of Development and Agricultural Economics, 2 (2010), 333-39.

Tamdoğan, Işık. 'Sulh and the 18 Th Century Ottoman Courts of Üsküdar and Adana', Islamic Law and Society, 15 (2008), 55-83.

Thanasegaran, Haemala. 'Growth of Islamic Insurance (Takaful) in Malaysia: A Model for the Region', Singapore Journal of Legal Studies, 2008 (2008), 143.

Triana, Nita. 'Reconstructing Sharia Economic Dispute Resolution Based on Indonesian Muslim Society Culture', Ijtimẩiyya: Journal of Muslim Society Research, 2 (2017), 107-28 <https://doi.org/10.24090/ ijtimaiyya.v2i1.1099>. 
Wahed, Hanes. 'Sulh: Its Application in Malaysia', IOSR Journal of Humanities and Social Sciences, 20 (2015), 71-79.

Wall, James A., John B. Stark, and Rhetta L. Standifer. 'Mediation: A Current Review and Theory Development', Journal of Conflict Resolution, 45 (2001), 370-91 <https://doi.org/10.1177/0022002 701045003006>. 